\title{
Natural disasters due to climate change in India
}

\section{Q NETHRAVATHI ASHOK PATIL, LAXMI N. TIRLAPUR AND BHEEMANAGOUDA O. PATIL}

Article Chronicle:

Received:

18.06.2015;

Revised :

28.10.2015;

Accepted :

12.11.2015

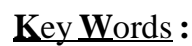

Avalanche, Flood, Land slide, Cyclone,

Earthquake
ABSTRACT : There is convincing evidence that changes in the earth's climate are taking place that cannot be explained without taking into account natural disasters. Trends in average conditions are much easier to identify than changes in extremes, largely because the latter are inherently episodic and rare. Precipitation events are getting more severe due to climate change. The study was conducted with an objective of analysing the trend in rainfall and temperature and death occurrence due to natural disasters in India. The present study was purely based on secondary data which was collected from Directorate of Economics and Statistics and National Crime Record Bureau, Ministry of Home Affairs from 1901 to 2012. The data was analysed using the Trend analysis (TCSI) and tabular analysis. Highest rainfall was during 1917(122.0mm)and lowest was during 2009(79.48mm). Highest Seasonal variation during April, May, June and July. Irregular variation ranges from 0.0085 to 0.01210 during the year 1917 to 1918, respectively. The minimum temperature in India was more during 1995(20.39 $\left.{ }^{\circ} \mathrm{C}\right)$ and highest maximum temperature was recorded during $2009\left(30.9^{\circ} \mathrm{C}\right)$. In the year 2012 percentage death due to cold and exposure (14.8\%), floods (420\%), heat stroke (1247\%), landslides (282\%), lightening (2263\%), torrential rains (203\%) and heat waves (263\%) was more compare to previous year. Highest death was occurred due to lighting, earth quake and heat stroke and least was death was due to avalanche and epidemic.

How to CITE THIS ARTICle : Patil, Nethravathi Ashok, Tirlapur, Laxmi N. and Patil, Bheemanagouda O. (2015). Natural disasters due to climate change in India. Asian J. Environ. Sci., 10(2): 142-149. 